Article

\title{
Sustainability Criteria and Indicators for the Bio-Based Economy in Europe: State of Discussion and Way Forward
}

\section{Uwe R. Fritsche ${ }^{1, *}$ and Leire Iriarte ${ }^{2}$}

1 International Institute for Sustainability Analysis and Strategy (IINAS), Heidelberger Str. 129 1/2, Darmstadt 64285, Germany

2 International Institute for Sustainability Analysis and Strategy (IINAS), C/Escuadra 11, Madrid 28012, Spain; E-Mail: li@iinas.org

* Author to whom correspondence should be addressed; E-Mail: uf@iinas.org; Tel.: +49-151-6284-8257.

External Editor: Calliope Panoutsou

Received: 3 June 2014; in revised form: 5 September 2014 / Accepted: 9 October 2014 / Published: 24 October 2014

\begin{abstract}
There is a strong interest in the EU to promote the bioeconomy sector within the EU 2020 strategy. It is thus necessary to assure a sound sustainability framework. This paper reviews international and European sustainability initiatives mainly for biomass for bioenergy. The basic and advanced sustainability indicators are identified and described with particular attention to those points without agreement between stakeholders. Based on the state of the discussion, some suggestions to enhance the sustainable development of the bioeconomy sector are proposed.
\end{abstract}

Keywords: sustainability; criteria and indicators; biomass; bioenergy; bioeconomy

\section{Introduction}

The bioeconomy is a cornerstone of the Europe 2020 Strategy [1]. The EU communication Innovating for Sustainable Growth: A Bioeconomy for Europe [1], states the need of a more sustainable resource use. Moreover, this EU Bioeconomy Action Plan [1] considers the development of standards and standardized sustainability assessment methodologies for bio-based products and food production systems. Hence, it seems unquestionable that the promotion of the bioeconomy will go along with 
sustainability requirements. Given the experience gained with the application of sustainability principles on particularly biomass for bioenergy, it seems clear that this could be a relevant entry point to build on for the sustainability strategy for the bioeconomy.

Sustainability of biomass for bioenergy has been extensively discussed within the context of new technological forms of bioenergy promotion. The debate was firstly focused on the sustainability of liquid biofuels i.e., bioethanol and biodiesel, and later it was extended to the solid bioenergy arena. Thus, since the very beginning of ambitious biomass for bioenergy targets, there was a clear demand from most stakeholders that the procurement of feedstocks take place according to a set of minimum sustainability requirements. Consequently, policy makers from various promoting countries - not exclusively from the EU but also from elsewhere (e.g., USA) - have linked the promotion of biomass for bioenergy to binding sustainability requirements. However, the vision of various stakeholders on what sustainability means is quite different and sometimes shows divergent points of view.

In the EU, the mandatory sustainability criteria [2] mainly refer to environmental considerations such as the protection of certain types of land with high biodiversity, high carbon stocks or peatlands, as well as to the greenhouse gas (GHG) savings. Despite the fact that socioeconomic aspects are also part of a comprehensive sustainability approach, these have not been taken into account in a meaningful way, at least within this mandatory initiative. Nonetheless, some EU Member States, such as the Netherlands [3], and ambitious voluntary guidelines, such as the Roundtable for Sustainable Biomaterials [4], take these aspects into consideration to varying extents.

Apart from the binding sustainability requirements specifically targeted to biomass for bioenergy, there are other levels of governance and other initiatives (see Section 2) that may shape the bioeconomy. These initiatives have to be acknowledged in developing a sustainable bioeconomy in order to avoid reinventing the wheel.

There are extensive efforts dealing with different aspects of sustainability, such as the identification of indicators, the establishment of adequate thresholds (e.g., [5]) or benchmarking of initiatives (e.g., $[6,7])$ to identify strengths and weaknesses of various standards.

Today at the global level, the total amount of biomass utilized for all human activities is approximately 179 EJ [8]. Of this, $72 \%$ is used in the food and feed sector, $27 \%$ is wood (for all uses) and the remaining 1\% is for fibers (e.g., textiles) [8]. In Europe, the food sector and household produce $90 \mathrm{Mt}$ of food wastes annually [1]. The wood sector harvested $577 \mathrm{Mm}^{3}$ in EU-27 in 2010 [9] mainly for materials and energy.

Currently, there is a lack of sound data on industrial material use and a survey on this is being conducted [10]. The bioeconomy is expected to play a relevant role in extending high-value biomass uses in the coming decades, and fostering cascading use of biomass as well as integrated multiple output systems such as biorefineries.

This paper reviews and discusses the extent to which the various levels of governance relevant to assure the sustainability of biomass for bioenergy and the extent to which these initiatives could be translated to the bioeconomy sector, including key points that need to be addressed for a sound development of the bioeconomy sector under basic and advanced sustainability criteria. It furthermore identifies some issues that should be clarified to efficiently move the development forward.

It is not the purpose of this paper to discuss those issues that have been already subject to extensive scientific work (such as a detailed description of potential impacts and respective indicators for biomass 
for bioenergy), but rather to highlight key points that need further work, and to propose a comprehensive sustainability framework for the bioeconomy sector.

\section{Governance of Sustainability of Biomass for Bioenergy}

Over the last few decades, much effort has been made to promote more sustainable management of natural resources. In addition to the various international conventions (e.g., Convention on Climate Change, Convention on Biological Diversity) there have been other attempts particularly targeting forests by means of various international processes on criteria and indicators for sustainable forest management, several regulations at different levels and voluntary forest certification schemes. The latter were promoted due to an increasing awareness regarding forests in general and tropical deforestation in particular. Later, when policies promoting biofuels for transport were introduced in several countries around the world, specific schemes to assure their sustainability were implemented in parallel. In more recent times, there have also been several initiatives to ensure sustainable use of solid bioenergy.

Table 1 provides an overview of selected initiatives to promote the sustainability of biomass for bioenergy with particular focus on solid biomass since the activities targeting liquid biofuels have been reviewed elsewhere (e.g., [11]). These activities are very diverse regarding:

- Type of scheme or regulation: mandatory or voluntary;

- Type of bioenergy: biofuels $v s$. solid $v s$. all types (including gaseous);

- Application level: international, regional or national;

- Sector of origin: mainly from energy, forestry or agriculture;

- Scope of sustainability: environmental vs. holistic approach.

Given the amount of partially overlapping initiatives, it seems obvious to build on existing efforts and promote synergies between the various activities when the sustainability of the bioeconomy is considered. First, a coherent framework for biomass when used for bioenergy is needed since there is still a lack of coherence on how to address sustainability if biomass is going to be used for biofuels or for heat and/or power. In this, both mandatory and voluntary schemes are relevant due to the different roles they play [12].

Table 1. Overview of Selected Sustainability Initiatives related to main types of Biomass for Bioenergy (Source: own compilation by IINAS).

\begin{tabular}{|c|c|}
\hline Activity & Brief Description \\
\hline GBEP & $\begin{array}{l}\text { - The Global Bioenergy Partnership endorsed Sustainability Indicators for } \\
\text { Bioenergy in 2011, aiming at national policy development [13]. }\end{array}$ \\
\hline $\begin{array}{l}\text { International } \\
\text { conventions }\end{array}$ & $\begin{array}{l}\text { - Within the Framework Convention on Climate Change there are instruments } \\
\text { associated with biomass such as REDD+ (Reducing Emissions from } \\
\text { Deforestation and Forest Degradation) that aim to create financial value for } \\
\text { carbon stored in forests [14] and the CDM (Clean Development Mechanism) that } \\
\text { allows implementing projects in non-Annex I parties of the Kyoto Protocol to } \\
\text { offset GHG emissions in Annex I countries [15]; } \\
\text { - The Convention on Biological Diversity and its Aichi targets that establish } \\
\text { several goals for biodiversity of various land uses [16]. }\end{array}$ \\
\hline
\end{tabular}


Table 1. Cont.

\begin{tabular}{|c|c|}
\hline Activity & Brief Description \\
\hline $\begin{array}{l}\text { International Forest } \\
\text { Processes }\end{array}$ & $\begin{array}{l}\text { - Non-legally binding instrument for all types of forests [17]; and } \\
\text { - Various on-going processes on criteria and indicators for sustainable forest } \\
\text { management (see e.g., [18]). }\end{array}$ \\
\hline EU Forest initiatives & $\begin{array}{l}\text { - The EU introduced in } 2003 \text { the Forest Law Enforcement, Governance and Trade } \\
\text { (FLEGT) Action Plan, in order to reduce deforestation in countries that export } \\
\text { timber products to the EU [19]; } \\
\text { - The EU Timber Regulation entered into effect in March 2013, aiming to avoid } \\
\text { entrance of illegally harvested timber products into the EU [20]; } \\
\text { - The EU Forest Strategy, adopted by the European Commission in } 2013 \text { [21]. }\end{array}$ \\
\hline $\begin{array}{l}\text { nternational } \\
\text { initiatives }\end{array}$ & $\begin{array}{l}\text { For example: } \\
\text { - IDB biofuels scorecard [22]; } \\
\text { - FAO Sustainable Woodfuel that gives principles, criteria and indicators with a } \\
\text { holistic approach [23]; } \\
\text { - FAO-UNEP-UN Energy Bioenergy Decision Support Tool [24]; } \\
\text { - GEF biofuel standards [25]. }\end{array}$ \\
\hline Standardization bodies & $\begin{array}{l}\text { - ISO The International Standardization Organization works on a standard } \\
\text { addressing sustainability issues related to bioenergy production (ISO 13065) [26]; } \\
\text { - CEN: The Working Group } 4 \text { (Sustainability criteria, life cycle analysis and } \\
\text { related issues) of the European Committee for Standardization TC411 Bio-based } \\
\text { products is working on the development of horizontal standards for bio-based } \\
\text { products [27]. }\end{array}$ \\
\hline $\begin{array}{l}\text { Voluntary Forest } \\
\text { Certification Schemes }\end{array}$ & $\begin{array}{l}\text { Emerged in early 1990s mainly to limit tropical deforestation, key are FSC [28] and } \\
\text { PFEC [29], as international umbrella standards with national implementation. }\end{array}$ \\
\hline $\begin{array}{l}\text { Voluntary forest } \\
\text { biomass harvesting } \\
\text { guidelines }\end{array}$ & $\begin{array}{l}\text { Guidance on reducing impacts of different woody biomass cultivation and } \\
\text { harvesting systems, e.g., in Finland, France, Germany, several Canadian and US } \\
\text { (see e.g., [30]). }\end{array}$ \\
\hline $\begin{array}{l}\text { Voluntary bioenergy } \\
\text { certification schemes } \\
\text { (biofuels and solid } \\
\text { bioenergy) }\end{array}$ & $\begin{array}{l}\text { Various schemes promoted by different stakeholders specifically targeting: } \\
\text { - Solid bioenergy: e.g., Green Gold Label [31], and Sustainable Biomass } \\
\text { Partnership [32] (though the latter is not a certification but reporting system); } \\
\text { - Liquid biofuels such as voluntary schemes already recognized by the EC to } \\
\text { comply with the RED requirements; } \\
\text { - All types of biomass for bioenergy such as the Roundtable on Sustainable } \\
\text { Biomaterials [4]. }\end{array}$ \\
\hline $\begin{array}{l}\text { Other voluntary } \\
\text { guidelines }\end{array}$ & $\begin{array}{l}\text { - The Voluntary Guidelines on the Responsible Governance of Tenure of Land, } \\
\text { Fisheries and Forests in the Context of National Food Security [33] aim to } \\
\text { contribute to the achievement of food security by acknowledging the central role } \\
\text { of land to development; } \\
\text { - The voluntary guidelines for responsible management of planted forests [34] } \\
\text { provide } 12 \text { guiding principles based on the institutional, economic, social and } \\
\text { cultural, environmental and landscape approach realms. }\end{array}$ \\
\hline
\end{tabular}


Table 1. Cont.

\begin{tabular}{l|l}
\hline \multicolumn{1}{c|}{ Activity } & \multicolumn{1}{c}{ Brief Description } \\
EU RED and related & $\begin{array}{l}\text { The European Union Renewable Energy Directive [2] established goals for biomass } \\
\text { and biofuels and include a list of sustainability requirements that specifically apply to } \\
\text { biofuels and bioliquids. There have been subsequent efforts from the EC [35] to } \\
\text { consider additional sustainability requirements with the aim of integrating indirect } \\
\text { effects and promoting advanced biofuels and on extending the RED criteria to solid } \\
\text { and gaseous bioenergy [36]. However, these initiatives have not been successfully } \\
\text { integrated in the regulation yet and it does not seem likely that they will be integrated } \\
\text { in the short term. }\end{array}$ \\
\hline $\begin{array}{l}\text { EU Member State } \\
\text { standards }\end{array}$ & $\begin{array}{l}\text { Major European countries importing (or with plans to import) woody biomass develop } \\
\text { specific sustainability schemes, e.g., Belgium, Denmark, the Netherlands, and the } \\
\text { UK [37]. } \\
\text { USA }\end{array}$ \\
\hline $\begin{array}{l}\text { RFS-Renewable Fuel Standard (federal level [38]); } \\
\text { RPS-Renewable Portfolio Standards (state level); } \\
\text { Biomass Crop Assistance Program (BCAP), which requires the demonstration } \\
\text { that woody feedstocks for energy cannot be used for higher value wood-based } \\
\text { product [39]. }\end{array}$ \\
\hline Bustainable forest management on provincial level (see e.g., [40]). \\
\hline $\begin{array}{l}\text { Agro-ecological zoning for sugarcane and eucalyptus in selected states [41]. This } \\
\text { mapping allows for determining the suitability of the land for cropping. For example, } \\
\text { the State of São Paulo has issued the resolution SMA 88/2008 that defines parameters } \\
\text { and guidelines for environmental licensing of sugarcane facilities based on the } \\
\text { agro-environmental zoning information. }\end{array}$ \\
\hline
\end{tabular}

\section{What Does Sustainability Mean?}

There are different approaches to sustainability (see e.g., [42] in the context of land management) and, as a result, various degrees of ambition are expressed through the diverse sustainability initiatives. This might be translated into basic and advanced sustainability criteria: the first establish only minimum requirements mainly for biodiversity protection and GHG emission reduction while the latter more demanding standards also consider more holistic issues such as soil, water, or social aspects, respectively. These different types of sustainability requirements can be applied within both regulatory frameworks and voluntary schemes.

The following subsections discuss the state-of-the-art for criteria in Table 2, with particular emphasis on sustainability risks of solid bioenergy from forests, and issues where the scientific community has not yet reached agreement. Topics such as air emissions, water, soil, food and fuelwood security as well as land tenure that have been extensively discussed elsewhere [5] are not considered in detail in this paper.

\subsection{Resource Efficiency}

Along the bioenergy chain (production, conversion and logistics), a minimum net energy yield should be achieved for both cultivated feedstocks, and residues. Previous work on this such as the Biomass Futures project [5] determined a minimum of $100 \mathrm{GJ} \cdot \mathrm{ha}^{-1}$ for land-based resources and 60 percent for residues and wastes. 
For woody bioenergy, the issue of cascading use of biomass is a contentious topic. Despite various efforts (e.g., [43,44]), there is not yet a consensus of what "cascading" means and how it should be applied. In general terms, the cascading approach aims at creating incentives to first use biomass for high-value products (e.g., chemicals, construction wood) and the residues from this production as well as post-consumer wood for other products of successively lower value. This means that priority is given to materially reuse and recycling biomass from discarded bio-based products before use for bioenergy. There are, however, restrictions to this concept:

- Not all biomass resources can be used for highest levels of value chains so that subsequent cascading of these feedstocks is limited. For example, certain forest residues are not suitable for sawn timber or even as feedstocks for pulp and paper;

- The value of biomass uses can vary between countries and circumstances. For example, woody biomass for modern energy uses may be more valuable in developing countries without (bio) chemical industries and high oil import cost, or in industrialized countries with high near-term GHG emission reduction targets which favor biomass co-firing.

There have been efforts to incorporate the cascading concept into legislation-in Belgium [45], for example — where solid biomass cannot be used for bioenergy as long as it could be used as material. However, at the EU level, the discussion whether and how to regulate cascading continues.

Based on discussions in the Biomass Policies project and the Dutch commission on sustainable biomass, a suggested additional criterion for resource efficiency is the relative "functionality" of specific biomass uses regarding societal preferences as expressed through market values. This criterion would use a simplified "ranking" indicator that prioritizes biomass uses. As all biomass uses can be characterized in terms of energy-using heating values, this indicator can be used for both bioenergy and material uses with the same metric.

Table 2. Comparison of basic and advanced sustainability criteria for biomass from bioenergy (Source: own compilation by IINAS).

\begin{tabular}{|c|c|c|}
\hline Criteria & Basic & Advanced \\
\hline Resource efficiency & & $\checkmark$ \\
\hline GHG savings & $\begin{array}{c}\checkmark \text { (minimum saving } \\
\text { thresholds) }\end{array}$ & $\checkmark$ (ambitious saving thresholds) \\
\hline $\begin{array}{l}\text { Biodiversity protection (no-go areas and } \\
\text { sustainable management in sourcing areas) }\end{array}$ & $\checkmark$ (only no-go areas) & $\begin{array}{l}\checkmark \text { (no-go areas and sustainable } \\
\text { management in sourcing areas) }\end{array}$ \\
\hline $\begin{array}{l}\text { Healthy livelihoods and labor conditions } \\
\text { (Adherence to ILO principles and } \\
\text { voluntary standards) }\end{array}$ & $\checkmark$ & $\checkmark$ \\
\hline Air emissions & & $\checkmark$ \\
\hline Soil & & $\checkmark$ \\
\hline Water & & $\checkmark$ \\
\hline Food, fuelwood and land tenure security & & $\checkmark$ \\
\hline
\end{tabular}




\subsection{Savings of Greenhouse Gas (GHG) Emissions}

This parameter is of utmost importance since one of the main reasons for biomass promotion is contributing to a decarbonized economy in general and particularly to GHG emission savings in comparison with the reference. Apart from the direct emissions considering a full life-cycle analysis, indirect emissions should be also considered because they might play an important role in the overall result particularly for some feedstocks.

Emissions accounting from woody biomass from forests deserve particular attention. When woody biomass is burnt for energy, the embodied $\mathrm{C}$ is released instantaneously as $\mathrm{CO}_{2}$ - quite different from the time over which wood left in the forest would have slowly decomposed, or from alternative uses for longer-living products. As forest regrowth is slow, especially during the first years after the final harvest, there is a period in which more $\mathrm{C}$ is emitted from forest bioenergy use than stored in the forest system. In sustainably managed forests, regrowth will diminish this temporal $\mathrm{C}$ imbalance over time. When considering the landscape level for $\mathrm{C}$ accounting, the $\mathrm{C}$ imbalance is less accentuated than at the stand level. Still, the dynamics of higher biogenic $\mathrm{C}$ emissions compared to many fossil fuels conflict with near-term policy targets for GHG emission reduction.

Given the current understanding of the global climate system, longer-term global temperature responses to higher emissions coupled with longer-term net emission reductions are uncertain, as there may be "tipping points" in the climate system with regard to emission levels and implied temperature changes. Thus, GHG emissions from forest bioenergy need to be evaluated with regard to both short- and longer-term targets, and for this, appropriate climate metrics are needed — which may result in risk levels rather than precise quantitative figures.

The scientific community is discussing how to address the climate impacts of solid bioenergy (e.g., $[46,47]$ ) but there is not yet a broad consensus on how to do it.

\subsection{Biodiversity Protection}

Reaching the CBD's Aichi targets requires not only the protection of some highly biodiverse areas such as old-growth forests, but also sustainable management of larger areas providing bioeconomy feedstocks. Increased supply could require higher intensification mainly in forest areas due to more intense thinning and harvesting (it is assumed that the land management intensity on agricultural land due to growing biofuel crops is the same as when growing crops for food or fiber). This intensification will vary depending on forest biome, and respective biodiversity impacts will vary accordingly.

Under a basic set of sustainability criteria it seems quite unlikely that the sustainability of "go areas" is applied in the short term due to the difficulty of regulating it. However, a more ambitious set of sustainability requirements should address the sustainability of providing feedstocks in go areas as well.

\section{The Way Forward}

Biomass serves different purposes — such as food, feed, fiber or energy — and an increasing demand of biomass for different uses within the bioeconomy sector, e.g., for bioplastics, biochemicals or bioliquids is expected. The share of domestic (EU biomass) and imported biomass will depend on issues such as policies, costs and type of sustainability requirements (see detailed analysis for woody biomass 
in [48]). The increase in demand for biomass to supply the bioeconomy and associated increases in pressures on natural resources, as well as the imperative need of increasing resource efficiency, make it necessary to develop a coherent sustainability framework regardless of the final use of biomass. Thus, the development of sustainability criteria just for biofuels (as e.g., in the EU) might lead to distortions between biomass-using sectors. Although significant efforts have been made (see Table 1), there is still a lack of coherence in intersectoral approaches. This needs to be overcome, acknowledging all types of biomasses for any purpose. For this, thinking in terms of land-based biological resources (applicable to most biomass resources but excluding secondary wastes and residues) might be useful.

In addition to thinking in the coverage of all sectors in which biomass might be used, it is also necessary to reconsider what sustainability is and how it should be applied both at the political level and the operational level. In this respect, the Bioeconomy Strategy aims to support developing an internationally shared understanding of biomass sustainability. A fundamental aspect of sustainability that needs to be considered is the creation of a level playing field for the value chains of biomass and fossil fuels. Equivalent sustainability requirements and sustainability performance indicators should then be applied to the biomass-based value chain, as well as the counterfactuals. Otherwise, there is an imminent risk that too demanding sustainability requirements for biomass-based value chains create a "sustainability leakage". In other words, similar comprehensive assessments should be carried out for all the systems providing equivalent end-uses.

Since biomass production and supply interact with many other sectors, it is necessary to consider many aspects of sustainability to adequately address its performance. Also, civil society and policy makers should make a decision on which of the specific indicators and respective thresholds might be acceptable. Science should inform on these minimum requirement with which biomass production and use should comply. A key example for such a minimum requirement is avoidingland-use changes in high-value ecosystems and land with high carbon stocks.

The performance of other indicators such as water, soils or employment should be assessed in any value chain and could serve as a multicriteria analysis that results in the overall performance. This might serve to evaluate the general performance of the value chain and hence contribute to make decisions when various value chains have to be screened.

Protecting the environment has been the key element when the sustainability criteria have been developed. However, the development of the bioeconomy should acknowledge and incorporate other social and economic criteria since increasing the demand for biomass might increase competition between uses and hence social issues would arise as for example in terms of land and respective land rights.

Many governance measures with various requirements regarding sustainability of biomass for bioenergy are in place. Given the proliferation of proposals, the development of an international framework of (minimum) standards has been suggested [49]. This could be a good basis to promote the development of a sound sustainability approach for the bioeconomy sector.

There are opportunities to both improve the understanding of what sustainability is as well as the ways to apply it. For this, a more comprehensive intrasectoral (for various types of biomass regardless of final use) and intersectoral approaches (from biomass use perspective and energy perspective) are needed. The experience acquired from developing sustainability requirements for biofuels (restricted criteria and indicators, fixed thresholds, relevance of indirect effects) should be considered when building the framework for sustainable bioeconomy. 


\section{Acknowledgments}

This work was supported by the Biomass Policies project-IEE 12/835/SI2.645920 funded by the European Union's Intelligent Energy Programme. Also, this work has benefited from additional work under the S2Biom project-Delivery of sustainable supply of non-food biomass to support a "resource-efficient" Bioeconomy in Europe-funded by the European Union's FP7-ENERGY Programme (project number 608622) and BioTrade2020+- Supporting a Sustainable European Bioenergy Trade Strategy-funded under European Union's Intelligent Energy Programme $/ 13 / 577 / \mathrm{S} 12.675534$.

\section{Author Contributions}

Uwe R. Fritsche took the lead in drafting "the way forward" and Leire Iriarte made the literature revision and elaborated the other sections. Together revised the last version of the manuscript.

\section{Conflicts of Interest}

The authors declare no conflict of interest.

\section{References and Notes}

1. Communication from the Commission to the European Parliament, the Council, the European Economic and Social Committee and the Committee of the Regions-Innovating for Sustainable Growth: A Bioeconomy for Europe; European Commission: Brussels, Belgium, 13 February 2013.

2. Directive 2009/28/EC of the European Parliament and of the Council of 23 April 2009 on the Promotion of the Use of Energy from Renewable Sources and Amending and Subsequently Repealing Directives 2001/77/EC and 2003/30/EC; European Union: Brussels, Belgium, 5 June 2009; pp. 16-62.

3. NTA 8080(en) Sustainability Criteria for Biomass for Energy Purposes; Netherlands technical agreement; Nederlands Normalisatie-Instituut: Delft, The Netherland, 2009.

4. Roundtable on Sustainable Biomaterials: RSB Principles and Criteria. Chatelaine. 2010. Available online: http://rsb.org/sustainability/rsb-sustainability-standards/ (accessed on 22 October 2014).

5. Fritsche, U.R.; Hennenberg, K.; Hünecke, K.; Wiegmann, K. Sustainable Bioenergy: Key Criteria and Indicators; Final D 4.1. Biomass Futures Project; Oeko-Institut: Darmstadt, Germany, March 2012.

6. Selecting a Biomass Certification System-A Benchmark on Level of Assurance, Costs and Benefits; NL Agency: Utrecht, The Netherlands, March 2012.

7. Schlamann, I.; Wieler, B.; Fleckenstein, M.; Walther-Thoß, J.; Haase, N.; Mathe, L. Searching for Sustainability: Comparative Analysis of Certification Schemes for Biomass used for the Production of Biofuels; WWF Deutschland: Berlin, Germany, November 2013.

8. Fritsche, U.R.; Iriarte, L.; Fitzgerald, J.; Bird, N. Sustainability Assurance for Energy from Forestry; International Institute for Sustainability Analysis and Strategy (IINAS): Darmstadt, Germany; European Forest Institute (EFI): Madrid, Spain; Joensuu, Finland; Joanneum Research (JR): Graz, Austria, June 2014; p. 59. 
9. Mantau, U. Wood Flows in Europe (EU27); Project Report; Confederation of European Paper Industries (CEPI) and European Confederation of Woodworking Industries (CEI-Bois): Brussels, Belgium, 2012; p. 24.

10. Rodríguez-Cerezo, E.; Parisi, C. Surveying the EU bio-based industry. In Proceedings of the Bioeconomy Observatory First Stakeholders Round Table, Brussels, Belgium, 26 November 2013.

11. Goovaerts, L.; Pelkmans, L.; Goh, C.S.; Junginger, M.; Joudrey, J.; Chum, H.; Smith, C.T.; Stupak, I.; Cowie, A.; Dahlman, L.; et al. Task 1: Examining Sustainability Certification of Bioenergy; IEA Bioenergy: Paris, France, February 2013.

12. Stupak, I.; Joudrey, J.; Smith, C.T.; Pelkmans, L.; Chum, H.; Cowie, A.; Dahlman, L.; Englund, O.; Goh, C.S.; Goss, A.; et al. Task 2: Survey on Governance and Certification of Sustainable Biomass and Bioenergy; IEA Bioenergy: Paris, France, February 2013.

13. The Global Bioenergy Partnership Sustainability Indicators for Bioenergy; Global Bioenergy Partnership (GBEP): Rome, Italy, December 2011.

14. REDD+. Reducing Emissions from Deforestation and Forest Degradation. Available online: http://www.un-redd.org/AboutREDD/tabid/102614/Default.aspx (accessed on 15 May 2014).

15. Clean Development Mechanism (CDM) Home Page. Available online: http://cdm.unfccc.int/ (accessed on 15 May 2014).

16. Convention on Biological Diversity-Aichi Biodiversity Targets. Available online: http://www.cbd.int/sp/targets/ (accessed on 15 May 2014).

17. Resolution Adopted by the General Assembly on 17 December 2007; United Nations General Assembly: New York, NY, USA, 31 January 2008.

18. Fritsche, U.R.; Iriarte, L.; de Jong, J.; Agostini, A.; Scarlat, N. Sustainability Criteria and Indicators for Solid Bioenergy from Forests; Outcome Paper of the Joint Workshops on Extending the RED Sustainability Requirements to Solid Bioenergy; IINAS: Darmstadt, Germany, December 2012.

19. Communication from the Commission to the Council and the European Parliament-Forest Law Enforcement, Governance and Trade (FLEGT); Proposal for an EU Action Plan; Commission of the European Communities: Brussels, Belgium, 2003.

20. Regulation (EU) No 995/2010 of the European Parliament and of the Council of 20 October 2010: Laying down the Obligations of Operators who Place Timber and Timber Products on the Market; European Union: Brussels, Belgium, November 2010.

21. Communication from the Commission to the European Parliament, the Council, the European Economic and Social Committee and the Committee of the Regions-A New EU Forest Strategy: For Forests and the Forest-based Sector; European Commission: Brussels, Belgium, 20 September 2013.

22. Inter-American Development Bank-Sustainability Scorecard. Available online: http://www.iadb. org/biofuelsscorecard (accessed on 15 May 2014).

23. Criteria and Indicators for Sustainable Woodfuels; FAO Forestry Paper 160; Food and Agricultural Organization of the United Nations: Rome, Italy, 2010.

24. UN-Energy Bioenergy Decision Support Tool. Available online: http://www. bioenergydecisiontool.org/ (accessed on 15 May 2014). 
25. Franke, B.; Fehrenbach, H.; Reinhardt, G.; Köppen, S.; Mueller-Lindenlauf, M.; Rettenmaier, N.; Gärtner, S.; Münch, J.; Malavelle, J.; Otto, M.; et al. Global Assessments and Guidelines for Sustainable Liquid Biofuels Production in Developing Countries; Final Report of A GEF Targeted Research Project; ifeu-Institute for Energyand Environmental Research Heidelberg: Heidelberg, Germany, 29 February 2012.

26. International Standardization Organization. TC 248 Project Committee: Sustainability Criteria for Bioenergy. Available online: http://www.iso.org/iso/home/standards_development/ list_of_iso_technical_committees/iso_technical_committee.htm?commid $=598379$ (accessed on 15 May 2014).

27. European Comittee for Standarization/TC411 Bio-Based Products. Working Group 4 Sustainability Criteria, Life Cycle Analysis and Related Issues. Available online: http://www.biobasedeconomy.eu/standardisation/cen-tc411/wg4/ (accessed on 15 May 2014).

28. Forest Stewardship Council. Available online: https://ic.fsc.org/ (accessed on 15 May 2014).

29. Program for the Endorsement of Forest Certification. Available online: http://www.pefc.org/ (accessed on 15 May 2014).

30. Fritsche, U.R.; Iriarte, L.; de Jong, J.; Agostini, A.; Scarlat, N. Extending the EU Renewable Energy Directive sustainability criteria to solid bioenergy from forests. Nat. Resour. Forum 2014, $38,129-140$.

31. Green Gold Label. Available online: http://www.greengoldcertified.org/site/pagina.php? (accessed on 15 May 2014).

32. Sustainable Biomass Partnership. Available online: http://www.sustainablebiomasspartnership.org/ (accessed on 15 May 2014).

33. Committee on World Food Security. Voluntary Guidelines on the Responsible Governance of Tenure of Land, Fisheries and Forests in the Context of National Food Security. Available online: http://www.fao.org/fileadmin/user_upload/nr/land_tenure/pdf/VG_Final_May_2012.pdf (accessed on 15 May 2014).

34. Responsible Management of Planted Forests: Voluntary Guidelines; Planted Forests and Trees Working Paper 37/E; Food and Agricultural Organization of the United Nations: Rome, Italy, 2006.

35. Proposal for a Directive of the European Parliament and of the Council amending Directive 98/70/EC Relating to the Quality of Petrol and Diesel Fuels and Amending Directive 2009/28/EC on the Promotion of the Use of Energy from Renewable Sources COM(2012) 595 Final; European Commission: Brussels, Belgium, 2012.

36. European Commission. Proposal for Directive of the European Parliament and of the Council on sustainability requirements for solid and gaseous biomass used in electricity and/or heating and cooling and biomethane injected into the natural gas grid. Unpublished internal draft, 2013.

37. Iriarte, L.; Fritsche, U.R. Pulpwood pellets from the US to the EU. In Impact of Promotion Mechanisms for Advanced and Low-iLUC Biofuels on Biomass Markets; Report to IEA Task 40; Pelkmans, L., Ed.; IEA Bioenergy: Paris, France, August 2014.

38. 40 CFR Part 80 Regulation of Fuels and Fuel Additives: Changes to Renewable Fuel Standard Program; Final Rule; Federal Register/Vol. 75, No. 58/Friday; U.S. Environmental Protection Agency: Washington, DC, USA, 26 March 2010. 
39. Kittler, B.; Price, W.; McDow, W.; Larson, B. Pathways to Sustainability: An Evaluation of Forestry Programs to Meet European Biomass Supply Chain Requirements; Environmental Defense Fund and Pinchot Institute: Washington, DC, USA, 2012.

40. Thiffault, E.; Llorente, M.; Murray, J.; Endres, J.M.; McCubbins, J.S.N.; Fritsche, U.R.; Iriarte, L. Ecological Sustainability of Solid Wood Bioenergy Feedstock Supply Chains: Local, National and International Policy Perspectives; Report to IEA Task 40; IINAS: Darmstadt, Germany, August 2014.

41. Fritsche, U.R.; Gress, H.W.; Iriarte, L.; Coelho, S.; Escobar, J. Possibilities of Sustainable Woody Energy Trade and Impacts on Developing Countries; IINAS: Darmstadt, Germany, January 2014.

42. Kaphengst, T. Towards a Definition of Global Sustainable Land Use? A Discussion on Theory, Concepts and Implications for Governance; GLOBALANDS Discussion Paper AP 3.1; Ecologic Institute: Berlin, Germany, January 2014.

43. Keegan, D.; Kretschmer, B.; Elbersen, B.; Panoutsou, C. Cascading use: A systematic approach to biomass beyond the energy sector. Biofuels Bioprod. Biorefining 2013, 7, 193-206.

44. Essel, R.; Breitmayer, E.; Carus, M.; Fehrenbach, H.; von Geibler, J.; Bienge K.; Baur, F.; Discussion Paper: Defining Cascading use of Biomass; R\&D-Project "Increasing Resource Efficiency by Cascading use of Biomass-From Theory to Practice" (FKZ 371344 100); nova-Institut GmbH: Huerth, Germany, 14 March 2014.

45. Pelkmans, L. 2013: Belgium-National Policy Landscape update. In Proceedings of the Biomass Policies Project Meeting, Brussels, Belgium, 25-27 November 2013.

46. Joint Research Centre of the European Commission, European Environment Agency; International Energy Agency Bioenergy Tasks 38, 40 and 43; International Institute for Sustainability Analysis and Strategy. Forests, bioenergy and climate change mitigation-Workshop outcome; In Proceedings of the Joint Workshop on Forests, Bioenergy and Climate Change Mitigation, Copenhagen, Denmark, 19-20 May 2014.

47. Lamers, P.; Junginger, M. The "debt" is in the detail: A synthesis of recent temporal forest carbon analyses on woody biomass for energy. Biofuels Bioprod. Biorefining 2013, 7, 373-385.

48. Forest Biomass for Energy in the EU: Current Trends, Carbon Balance and Sustainable Potential; Final Report, Prepared for BirdLife Europe, EEB, and Transport \& Environment; IINAS: Darmstadt, Germany; EFI: Madrid, Spain; Joensuu, Finland; JR: Graz, Austria, May 2014.

49. Pelkmans, L.; Goovaerts, L.; Smith, C.T.; Joudrey, J.; Stupak, I.; Englund, O.; Junginger, M.; Goh, C.S.; Chum, H.; Cowie, A. Recommendations for improvement of sustainability certified markets. Available online: http://bioenergytrade.org/downloads/iea-sust-cert-task-4-final2013.pdf (accessed on 13 May 2014).

(C) 2014 by the authors; licensee MDPI, Basel, Switzerland. This article is an open access article distributed under the terms and conditions of the Creative Commons Attribution license (http://creativecommons.org/licenses/by/4.0/). 